\title{
An investigation into the shelf life and consumer acceptability of flavored cold coffee drink
}

\section{Aromalı soğuk kahve içeceğinin raf ömrü ve tüketici beğenisi üzerine bir araştırma}

\author{
Ahmet Oğuzhan POLAT ${ }^{*}$ (D), Şenol IBANOĞLU ${ }^{(D)}$ \\ ${ }^{1}$ Meridyen Gıda, 5. Organize Sanayi Bölgesi, 83539 Nolu Cad., No 16/1, Gaziantep, Turkey \\ ${ }^{2}$ University of Gaziantep, Engineering Faculty, Food Engineering Department, 27310 Gaziantep, Turkey
}

${ }^{1}$ https://orcid.org/0000-0003-1069-3712; ${ }^{2}$ https://orcid.org/0000-0002-0727-4747

\section{To cite this article:}

Polat, A.O., \& ibanoğlu, Ş. (2021). An investigation into the shelf life and consumer acceptability of flavored cold coffee drink. Harran Tarım ve Gida Bilimleri Dergisi, 25(4): 534545.

DOI: $10.29050 /$ harranziraat.862698

*Address for Correspondence: Ahmet Oğuzhan POLAT e-mail:

ahmetoguzhanpolat@gmail.com

Received Date:

16.01.2021

Accepted Date:

26.10.2021

(C) Copyright 2018 by Harran University Faculty of Agriculture. Available on-line at www.dergipark.gov.tr/harranziraat

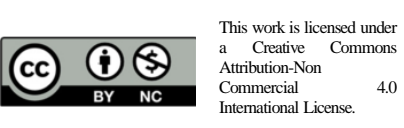

\section{ABSTRACT}

In this article, it was aimed to develop a method to determine the shelf life of pistachio nut flavored cold coffee. The shelf life of flavored cold coffee was determined by the Weibull hazard analysis method. While a fixed time (i.e., $10 \mathrm{~min}$ ) was applied for the sterilization process, different sterilization temperatures (i.e., 110,120 and $125^{\circ} \mathrm{C}$ ) were used. In the first stage of the study, while carrageenan gum was added as a thickener to all cold coffees, sodium bicarbonate, which is an acidic regulator, was not added. The shelf lives of products sterilized in this way were determined as 14,28 and 18 days at $110^{\circ} \mathrm{C}, 120^{\circ} \mathrm{C}$ and $125^{\circ} \mathrm{C}$, respectively. In the second step, both sodium bicarbonate and carrageenan gum were added to the samples and the shelf life of the product, which was sterilized at $120^{\circ} \mathrm{C}$ for $10 \mathrm{~min}$., was calculated as 16 months and 9 days. As a result of the hedonic tests, $71 \%$ of the panelists stated that they liked pistachio flavored cold coffee. The optimum formulation of cold coffee was $1.5 \%(\mathrm{w} / \mathrm{w})$ coffee, $0.2 \%(\mathrm{w} / \mathrm{w})$ sodium bicarbonate, $7.5 \%(\mathrm{w} / \mathrm{w})$ sugar, $5.0 \%(\mathrm{w} / \mathrm{w}) \mathrm{milk}$ powder, $0.1 \%(w / w)$, chewing gum and $0.1 \%(w / w)$ pistachio flavor.

Key Words: Cold coffee, Pistachio nut flavor, Shelf life, Weibull hazard analysis

\section{Öz}

Bu makalede, Antep fıstığı aromalı soğuk kahvenin geliştirilmesi ve raf ömrünün belirlenmesi amaçlanmıştır. Aromalı soğuk kahvenin raf ömrü Weibull tehlike analizi yöntemiyle belirlenmiştir. Sterilizasyon işlemi için sabit süre (10 dk.) uygulanırken farklı sterilizasyon sıcaklıkları $\left(110,120\right.$ ve $\left.125^{\circ} \mathrm{C}\right)$ kullanılmıştır. Çalışmanın ilk aşamasında bütün soğuk kahvelere kıvam arttırıcı olarak karagenan zamkı eklenirken, asidik düzenleyici olan sodyum bikarbonat eklenmemiştir. Bu şekilde sterilize edilen ürünlerin raf ömürleri $110^{\circ} \mathrm{C}, 120^{\circ} \mathrm{C}$ ve $125^{\circ} \mathrm{C}$ 'de sırasıyla 14,28 ve 18 gün olarak belirlenmiştir. Araştırmanın ikinci aşamasında ise hem sodyum bikarbonat hem de karagenan zamkı eklenmiş ve $120^{\circ} \mathrm{C}$ de 10 dakika sterilize edilen ürünün raf ömrü 16 ay 9 gün olarak hesaplanmıştır. Hedonik testler sonucunda panelistlerin \%71'i Antep fıstık aromalı soğuk kahveyi beğendiklerini ifade etmişlerdir. Soğuk kahvenin optimum formülasyonu ise \%1.5 (a/a) kahve, \%0.2 (a/a) sodyum bikarbonat, \%7.5 (a/a) şeker, \%5.0 (a/a) süt tozu, \%0.1 (a/a), sakız ve \%0.1 (a/a) fıstık aroması olarak belirlenmiştir.

Anahtar Kelimeler: Soğuk kahve, Antep fıstığı aroması, Raf ömrü, Weibull tehlike analizi

\section{Introduction}

Coffee is an important product belonging to the Rubiaceae and Cinchonoidea sub family.
Although there are more than eighty types of coffee obtained from the beans of the Coffea $\mathrm{L}$. plant, only two of these types are of commercial importance worldwide (i.e., Coffea Arabica and 
Coffea Canephora). These two species differ in many respects such as the climate in which they grow, their chemical composition and the brewing characteristics of the ground-roasted seed. Today, consumption of Arabica with its sensory features is quite common and it is more expensive than Robusta (Araujo and Sandi, 2006). According to the reports of the International Coffee Organization (ICO), an average of more than 5 million kilograms of coffee is consumed annually in the world (ICO, 2017). The annual coffee consumption in Turkey is 45 thousand tons that appeared around 6.5 billion, and this amount corresponds to a daily cup 17.7 million cups of coffee (ICO, 2017).

Increasingly popular in recent years, cold coffee has varieties such as latte, mocha, vanilla and espresso. In this field where there is little variety, it is very important to develop alternative new products that consumers may like. Shelf life is defined as the storage time during which food products remain safe without any change in the desired sensory, chemical, physical and microbiological properties (Kilcast and Subramaniam, 2000). Many methods can be used to determine the shelf life. Weibull hazard analysis is based on the principle of predicting when the shelf life will end using the Weibull hazard function (Cardelli and Labuza, 2000).

In order for a food item to be preferred, the desired organoleptic characteristics such as taste, aroma, texture, color and appearance should appeal to the consumer. Only in this way will a food item cause a desire to be bought again (Moskowitz et al., 2009). Therefore, during the development process of the new product, the reliability, durability and preferability of the new product produced by the consumers should also be tested (Akbulut and Bozkurt, 2020; Hayoğlu and Toğrul, 2020). Sensory analysis is one of the most important elements of the preference of foodstuffs and the determination of shelf life. The Weibull hazard analysis is a method used in the determination of shelf life using sensory data (Fu and Labuza, 1997; Karahan and Keklik, 2018). There are many research studies on the determination of shelf life of luncheon meats (Gacula and Kubala, 1975), cassava flour (Shiroseet et al., 1978), breakfast cereal (Pickering, 1984), ice cream (Wittinger and Smith, 1986), refrigerated meats (Andujar and Herrera, 1987), frozen foods (Tomasicchio, 1989), cottage cheese (Schmidt and Bouma, 1992), pasteurized milk (Duyveste, 1997), and sausages (Thiemig et al., 1998). Data analysis entails graphing hazard values against time and using the Weibull distribution to calculate shelf life, which is defined as the time at which $50 \%$ of customers find the product unsatisfactory. This approach was named as the Weibull hazard analysis technique by Labuza and Schmidt (1988) and Fu and Labuza (1993).

Flavored cold coffee drinks, which have attracted attention in the market recently, are also produced industrially in Turkey. As far as is known, the flavors of cold coffee drinks produced are limited to vanilla, chocolate and caramel. In this study, it was aimed to develop a new 'cold coffee drink' with pistachio aroma whose formulation was optimized in line with the consumer's taste, whose shelf life was determined and which differs from the products on the market in terms of aroma. In this context, the purpose of our work was to optimize the formulation of the product and determining the shelf life for the production of the cold coffee beverage.

\section{Materials and Methods}

\section{Materials}

Defatted milk powder (ARC, Konya, Turkey), sodium bicarbonate (Şişecam, Beydağı Kimya, İstanbul, Turkey), coffee extract (Arabica, Brenntag, Germany), carrageenan gum (MM 901, Cargill Inc., Orhangazi, Turkey), sucrose (Beşan Nişasta, Gaziantep, Turkey) and pistachio nut flavor (Brenntang, Germany) were used to prepare the cold coffee samples. A homogenizer (Hommak 10000-E-HM150, Germany) and an autoclave (Lubeca, Poland) were used during production of coffee samples. 


\section{Methods}

\section{Preparation of samples}

The production flow chart for the preparation of cold coffee samples is shown in Figure 1. Various trials were carried out with panelists to determine the formulation of the popular pistachio flavored cold coffee. In order to determine the formulation of coffee, many different formulations were tried (data not given) and finally the following recipe was used. As a result of these trials, the formulation of the popular cold coffee was determined as $1.5 \%$ $(\mathrm{w} / \mathrm{w})$ coffee, $0.2 \%(\mathrm{w} / \mathrm{w})$ sodium bicarbonate,
$7.5 \%(\mathrm{w} / \mathrm{w})$ sugar, $5.0 \%(\mathrm{w} / \mathrm{w})$ milk powder, $0.1 \%$ $(\mathrm{w} / \mathrm{w})$ carrageenan gum, $0.1 \%(\mathrm{w} / \mathrm{w})$ pistachio flavor and $85.6 \%(\mathrm{w} / \mathrm{w})$ purified water. The cold coffee samples were prepared according to above formulation. The product was homogenized at $70^{\circ} \mathrm{C}$ at 200 bars. The homogenized product was filled in $200 \mathrm{~mL}$ single layer lacquered tin box. The products were then placed into autoclave and were sterilized at the appropriate temperature and time in the autoclave. Autoclave was used at 110, 120 and $125^{\circ} \mathrm{C}$ for 10 minutes. After sterilization process, the products were stored at room temperature.

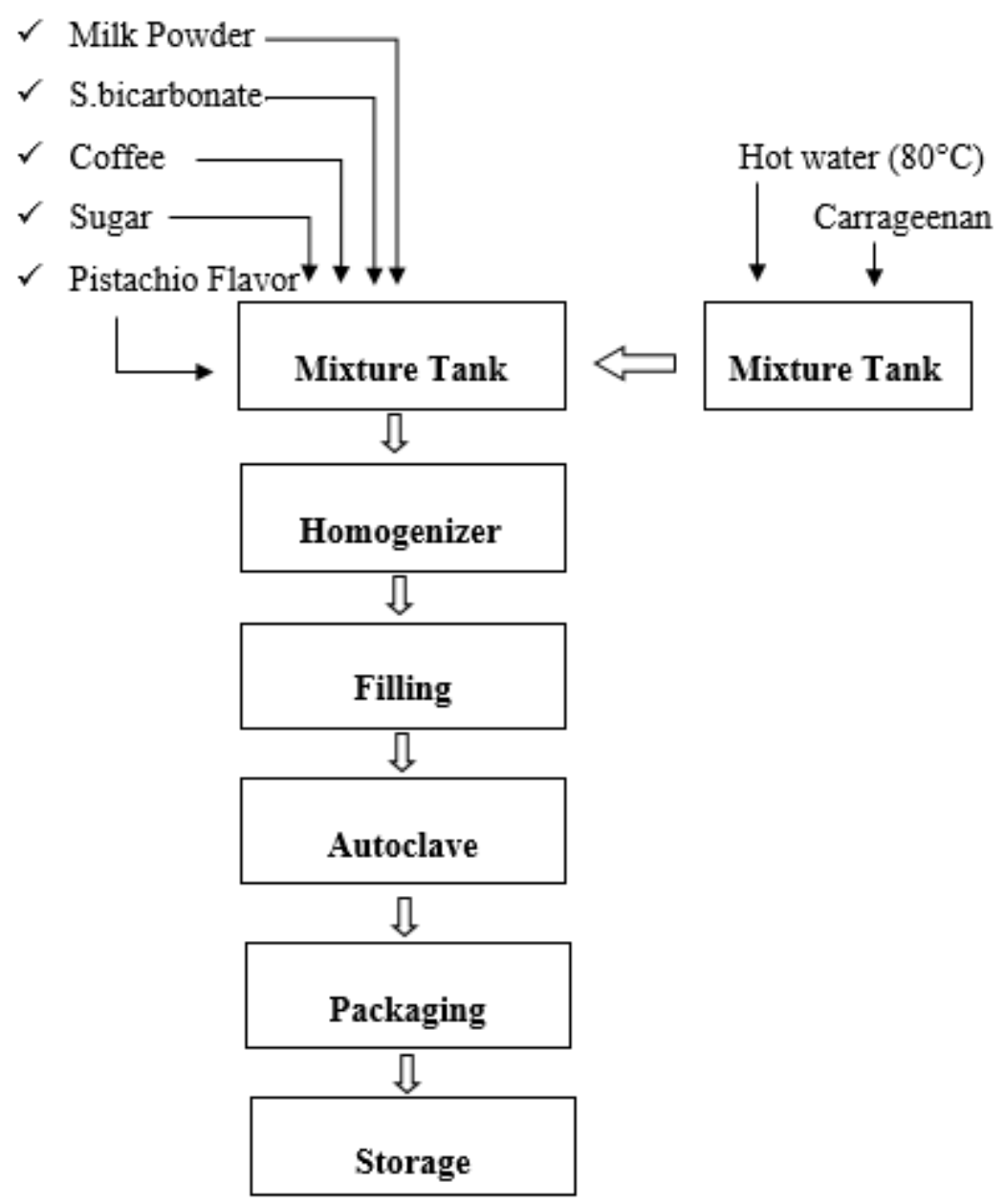

Figure 1. Flow chart of cold coffee production with pistachio flavor.

Determination of the shelf life of cold coffee using Weibull hazard analysis

The shelf life of cold coffee was calculated with the Weibull hazard method and sensory analysis was carried out using the Weibull method. In this sense, 3 sterilization temperature were used in this study, namely $110^{\circ} \mathrm{C}$ for $10 \mathrm{~min}, 120^{\circ} \mathrm{C}$ for 10 $\min$ and $125^{\circ} \mathrm{C}$ for $10 \mathrm{~min}$. Sensory analysis was performed by panelists who have previously tasted products. Panelists were selected from university students. Prior to the sensory analysis, basic training information's for the analysis were given to all panelists. Sensory analysis was repeated every 5 days. For the first trials, 100 panelists were determined and panelists rated the product as acceptable (+) or unacceptable (-). 
The number of panelists was increased by 1 person with each trial. When the (-) result was equal to or greater than $(+)$ result, new panelists were added next trial as many as the number of panelists that gave (-) results in the previous try. Weibull cumulative hazard function was calculated as described by (Fu and Labuza, 1997) (Equation 1).

$$
H(t)=\int h(x) d x=(t / \alpha)^{\beta}
$$

In this function; $H(t)$ is cumulative hazard function; $h(x)$ is hazard function; $t$ is the time, $\alpha$ is scale parameter and $\beta$ is shape parameter. To calculate hazard parameters, log (time) vs log (cumulative hazard values) was plotted. The equation obtained from the graph was replaced in Equation 2 (Keklik et al., 2017).

$\log t=(1 / \beta) \log H+\log \alpha$

In the Weibull hazard analysis; shelf life is 50\% of the probability of critical error. In other words, it is defined as the period corresponding to the 69.3\% cumulative hazard value (Fu and Labuza, 1997).

Determination of the aroma of cold coffee and optimization of its formula

Sensory analysis was performed by hedonic method to determine the aroma of cold coffee and to determine the sensory quality characteristics. In this context, the panelists were asked to record the degree of liking for a sample from "extreme distaste" to "extreme like" (Carpenter et al., 2000). Sensory analysis evaluation was carried out by 100 panelists, while 71 of the 100 selected panelists preferred the cold coffee with pistachio.

\section{Statistical analyses}

Analysis of variance (ANOVA), Duncan's multiple comparison test analysis and coefficient of variations (CV) tests were performed using SPSS (SPSS, Inc., Chicago, USA) with $P<0.05$ level as the confidence interval. Triplicate samples were used for all analyses.

\section{Results and Discussion}

Determination of the aroma of cold coffee and optimization of its formula

Sensory analysis was performed by hedonic method to determine the aroma of cold coffee and to determine the sensory quality characteristics. In a study by Shakerardekani et al. (2012) it was aimed to develop a milk drink containing pistachio flavor. Sensory analysis of the new product was made to by soaking and grinding pistachio kernels. The prepared pistachio milk samples received 8.2 points by the panelists and the pistachio flavor was acceptable for this new product (Shakerardekani et al., 2012). Pistachio nut offers new opportunities for use in new products with improved aroma, odor, mouth feel, texture and taste.

Determination the shelf life of cold coffee at different temperature at constant time without sodium bicarbonate acidity regulator and with carrageenan gum

Trial 1: Sterilization process at $110^{\circ} \mathrm{C}$ and 10 minutes without sodium bicarbonate and with carrageenan

In this trial, it was aimed to calculate the shelf life of the sample product with a sterilization process at $110^{\circ} \mathrm{C}$ and 10 minutes without sodium bicarbonate and with carrageenan. The sensory analysis made started with 10 panelists and was concluded with 32 panelists at the end of the 16th day (Table 1 ). 
Table 1 . Weibull sensory data for cold coffee at $110^{\circ} \mathrm{C}$ and $10 \mathrm{~min}$ without sodium bicarbonate and with carrageenan

\begin{tabular}{|c|c|c|c|c|c|c|c|c|c|c|c|c|c|c|c|c|}
\hline Days & Acce & abili & & & & & & & & & & & & & & \\
\hline 0 & + & + & + & + & + & + & + & + & + & + & & & & & & \\
\hline 5 & + & + & + & + & + & + & + & + & + & + & + & & & & & \\
\hline 10 & + & + & + & + & + & -32 & -33 & -34 & -35 & -36 & -37 & -38 & & & & \\
\hline \multirow[t]{2}{*}{13} & + & + & + & + & + & + & + & + & + & -21 & -22 & -23 & -24 & -25 & -26 & -27 \\
\hline & -28 & -29 & -30 & -31 & & & & & & & & & & & & \\
\hline \multirow[t]{2}{*}{16} & + & + & + & + & + & + & + & + & + & + & + & + & -1 & -2 & -3 & -4 \\
\hline & -5 & -6 & -7 & -8 & -9 & -10 & -11 & -12 & -13 & -14 & -15 & -16 & -17 & -18 & -19 & -20 \\
\hline
\end{tabular}

Table 2. Weibull hazard $(\mathrm{H})$ ranking data for cold coffee at $110^{\circ} \mathrm{C}$ and $10 \mathrm{~min}$ without sodiumnbicarbonate and with carrageenan gum

\begin{tabular}{|c|c|c|c|}
\hline Rank & Days & H Value & $\sum \mathrm{H}$ \\
\hline 38 & 10 & 2.63 & 2.63 \\
\hline 37 & 10 & 2.70 & 5.33 \\
\hline 36 & 10 & 2.78 & 8.11 \\
\hline 35 & 10 & 2.86 & 10.97 \\
\hline 34 & 10 & 2.94 & 13.91 \\
\hline 33 & 10 & 3.03 & 16.94 \\
\hline 32 & 10 & 3.13 & 20.07 \\
\hline 31 & 13 & 3.23 & 23.29 \\
\hline 30 & 13 & 3.33 & 26.62 \\
\hline 29 & 13 & 3.45 & 30.07 \\
\hline 28 & 13 & 3.57 & 33.64 \\
\hline 27 & 13 & 3.70 & 37.35 \\
\hline 26 & 13 & 3.85 & 41.19 \\
\hline 25 & 13 & 4.00 & 45.19 \\
\hline 24 & 13 & 4.17 & 49.36 \\
\hline 23 & 13 & 4.35 & 53.71 \\
\hline 22 & 13 & 4.55 & 58.25 \\
\hline 21 & 13 & 4.76 & 63.02 \\
\hline 20 & 16 & 5.00 & 68.02 \\
\hline 19 & 16 & 5.26 & 73.28 \\
\hline 18 & 16 & 5.56 & 78.83 \\
\hline 17 & 16 & 5.88 & 84.72 \\
\hline 16 & 16 & 6.25 & 90.97 \\
\hline 15 & 16 & 6.67 & 97.63 \\
\hline 14 & 16 & 7.14 & 104.78 \\
\hline 13 & 16 & 7.69 & 112.47 \\
\hline 12 & 16 & 8.33 & 120.80 \\
\hline 11 & 16 & 9.09 & 129.89 \\
\hline 10 & 16 & 10.00 & 139.89 \\
\hline 9 & 16 & 11.11 & 151.00 \\
\hline 8 & 16 & 12.50 & 163.50 \\
\hline 7 & 16 & 14.29 & 177.79 \\
\hline 6 & 16 & 16.67 & 194.46 \\
\hline 5 & 16 & 20.00 & 214.46 \\
\hline 4 & 16 & 25.00 & 239.46 \\
\hline 3 & 16 & 33.33 & 272.79 \\
\hline 2 & 16 & 50.00 & 322.79 \\
\hline 1 & 16 & 100.00 & 422.79 \\
\hline
\end{tabular}

After the sensory evaluation, (-) answers were listed and the cumulative hazard $(\Sigma \mathrm{H})$ and hazard values $(H)$ were determined. In this calculation $H$ value was equal to 100 / sequence number (Table 2). In Weibull hazard analysis shelf life to $50 \%$ of critical error probability, $69.3 \%$, is defined as the time corresponding to the cumulative hazard value (Fu and Labuza, 1997) (Figure 2).

Trial 2: Sterilization process at $120^{\circ} \mathrm{C}$ and 10 minutes without sodium bicarbonate and with carrageenan

In this trial, the sterilization step was completed at $120^{\circ} \mathrm{C}$ and 10 minutes. Sensory analysis started with 10 panelists and concluded with 37 panelists at the end of the 36th day. The steps of the Weibull analysis method used in the trial number 1 were also applied in the same way in this study. The hazard values ( $\mathrm{H}$ values) and cumulative hazard values $(\Sigma \mathrm{H})$ obtained as a result of the sensory evaluation are shown in Table 3. 


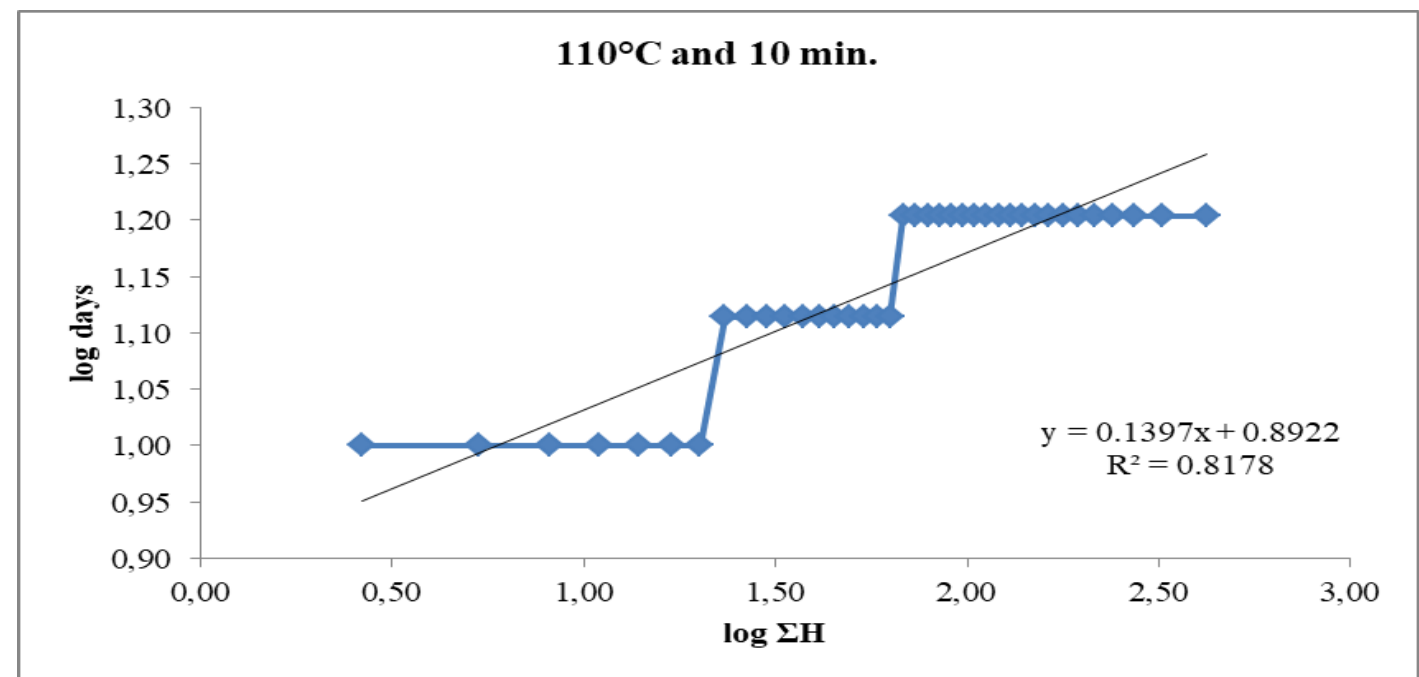

Figure 2. Weibull hazard plot for cold coffee at $110^{\circ} \mathrm{C}$ and $10 \mathrm{~min}$ without sodium bicarbonate ( $\Sigma \mathrm{H}$ : cumulative hazard).

Table 3. Weibull sensory data for cold coffee at $120^{\circ} \mathrm{C}$ and 10 min without sodium bicarbonate and with carrageenan

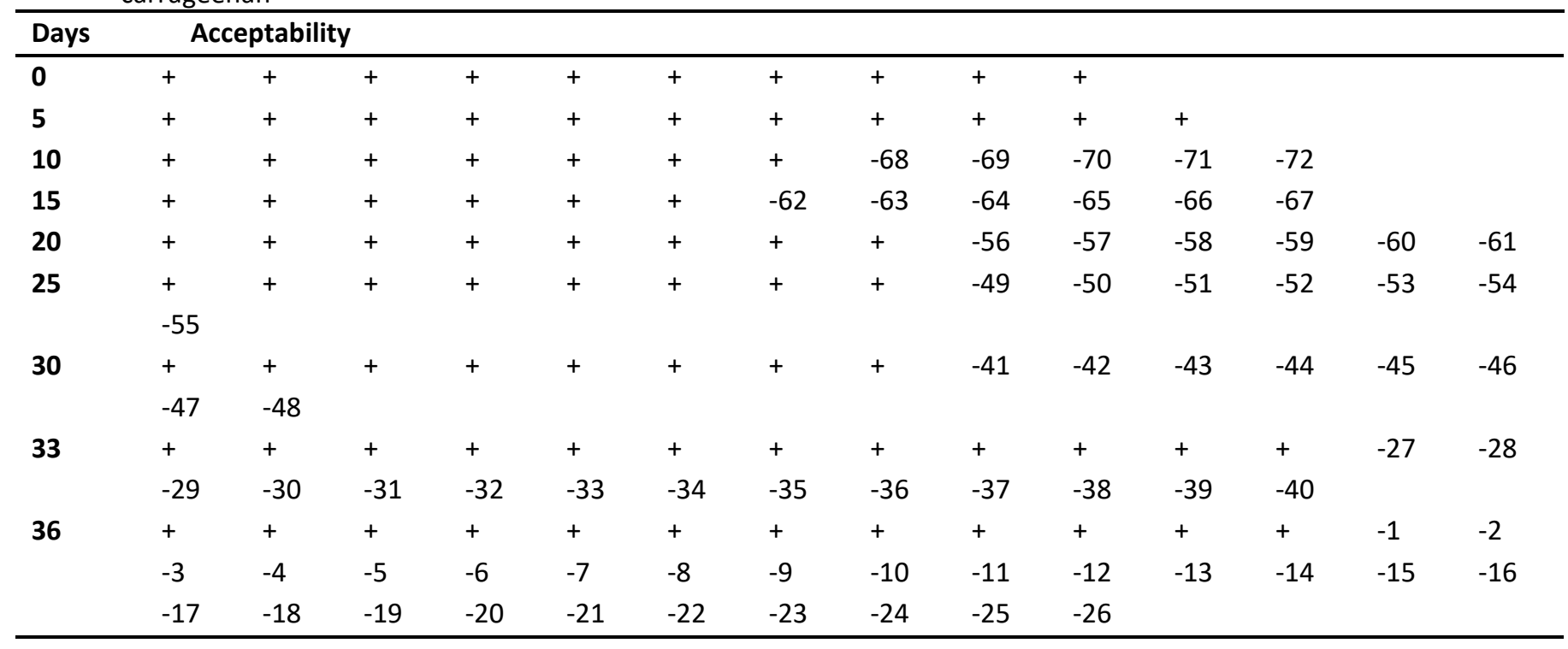

The graph of the logarithm of the cumulative time $(\log t)$ is shown in Figure 3. hazard values $(\log \Sigma \mathrm{H})$ versus the logarithm of

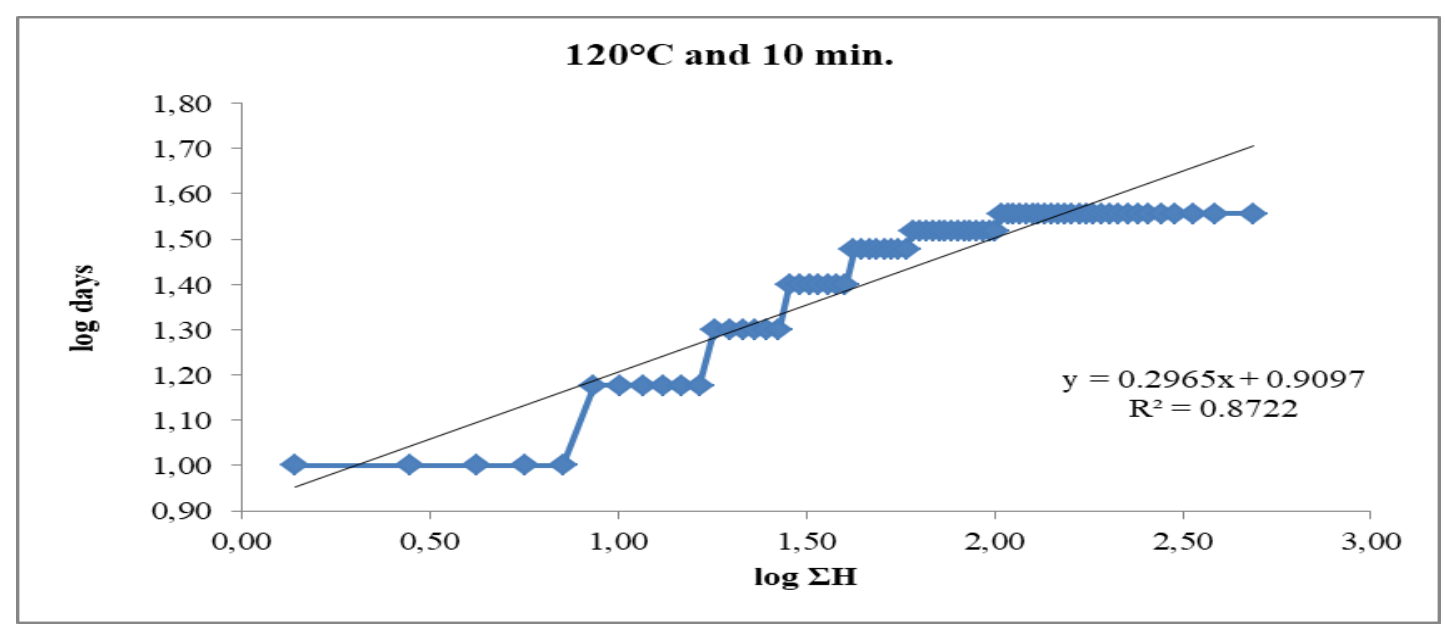

Figure 2. Weibull hazard plot for cold coffee at $120^{\circ} \mathrm{C}$ and 10 min without sodium bicarbonate and with carrageenan. 
Polat and ibanoğlu, 2021. Harran Tarım ve Gıda Bilimleri Dergisi, 25(4): 534-545

Table 4. Weibull hazard ranking table for cold coffee at $120^{\circ} \mathrm{C}$ and $10 \mathrm{~min}$ without sodium bicarbonate and with carrageenan gum

\begin{tabular}{|c|c|c|c|c|c|c|c|}
\hline Rank & Day & $\mathrm{H}$ Value & $\sum \mathrm{H}$ & Rank & Day & $\mathrm{H}$ Value & $\sum \mathrm{H}$ \\
\hline 72 & 10 & 1.39 & 1.39 & 36 & 33 & 2.78 & 71.40 \\
\hline 71 & 10 & 1.41 & 2.80 & 35 & 33 & 2.86 & 74.26 \\
\hline 70 & 10 & 1.43 & 4.23 & 34 & 33 & 2.94 & 77.20 \\
\hline 69 & 10 & 1.45 & 5.68 & 33 & 33 & 3.03 & 80.23 \\
\hline 68 & 10 & 1.47 & 7.15 & 32 & 33 & 3.13 & 83.36 \\
\hline 67 & 15 & 1.49 & 8.64 & 31 & 33 & 3.23 & 86.58 \\
\hline 66 & 15 & 1.52 & 10.15 & 30 & 33 & 3.33 & 89.92 \\
\hline 65 & 15 & 1.54 & 11.69 & 29 & 33 & 3.45 & 93.36 \\
\hline 64 & 15 & 1.56 & 13.25 & 28 & 33 & 3.57 & 96.94 \\
\hline 63 & 15 & 1.59 & 14.84 & 27 & 33 & 3.70 & 100.64 \\
\hline 62 & 15 & 1.61 & 16.45 & 26 & 36 & 3.85 & 104.49 \\
\hline 61 & 20 & 1.64 & 18.09 & 25 & 36 & 4.00 & 108.49 \\
\hline 60 & 20 & 1.67 & 19.76 & 24 & 36 & 4.17 & 112.65 \\
\hline 59 & 20 & 1.69 & 21.46 & 23 & 36 & 4.35 & 117.00 \\
\hline 58 & 20 & 1.72 & 23.18 & 22 & 36 & 4.55 & 121.55 \\
\hline 57 & 20 & 1.75 & 24.93 & 21 & 36 & 4.76 & 126.31 \\
\hline 56 & 20 & 1.79 & 26.72 & 20 & 36 & 5.00 & 131.31 \\
\hline 55 & 25 & 1.82 & 28.54 & 19 & 36 & 5.26 & 136.57 \\
\hline 54 & 25 & 1.85 & 30.39 & 18 & 36 & 5.56 & 142.13 \\
\hline 53 & 25 & 1.89 & 32.28 & 17 & 36 & 5.88 & 148.01 \\
\hline 52 & 25 & 1.92 & 34.20 & 16 & 36 & 6.25 & 154.26 \\
\hline 51 & 25 & 1.96 & 36.16 & 15 & 36 & 6.67 & 160.92 \\
\hline 50 & 25 & 2.00 & 38.16 & 14 & 36 & 7.14 & 168.07 \\
\hline 49 & 25 & 2.04 & 40.20 & 13 & 36 & 7.69 & 175.76 \\
\hline 48 & 30 & 2.08 & 42.28 & 12 & 36 & 8.33 & 184.09 \\
\hline 47 & 30 & 2.13 & 44.41 & 11 & 36 & 9.09 & 193.18 \\
\hline 46 & 30 & 2.17 & 46.59 & 10 & 36 & 10.00 & 203.18 \\
\hline 45 & 30 & 2.22 & 48.81 & 9 & 36 & 11.11 & 214.30 \\
\hline 44 & 30 & 2.27 & 51.08 & 8 & 36 & 12.50 & 226.80 \\
\hline 43 & 30 & 2.33 & 53.41 & 7 & 36 & 14.29 & 241.08 \\
\hline 42 & 30 & 2.38 & 55.79 & 6 & 36 & 16.67 & 257.75 \\
\hline 41 & 30 & 2.44 & 58.23 & 5 & 36 & 20.00 & 277.75 \\
\hline 40 & 33 & 2.50 & 60.73 & 4 & 36 & 25.00 & 302.75 \\
\hline 39 & 33 & 2.56 & 63.29 & 3 & 36 & 33.33 & 336.08 \\
\hline 38 & 33 & 2.63 & 65.92 & 2 & 36 & 50.00 & 386.08 \\
\hline 37 & 33 & 2.70 & 68.63 & 1 & 36 & 100.00 & 486.08 \\
\hline
\end{tabular}

In trial 2, the shelf life was calculated using the Weibull hazard analysis method and the shelf life of the new product was determined as 28.6 days.

Trial 3: Sterilization process at $125^{\circ} \mathrm{C}$ and 10 minutes, without sodium bicarbonate and with carrageenan

In this try, sterilization process was carried out at $125^{\circ} \mathrm{C}$ and 10 minutes. The sensory evaluation started with 10 panelists and was concluded on the 21 st day with the participation of 36 panelists in total (Table 5, Figure 4). 
Table 5. Weibull sensory data for cold coffee at $125^{\circ} \mathrm{C}$ and $10 \mathrm{~min}$ without sodium bicarbonate and with Carrageenan

\begin{tabular}{|c|c|c|c|c|c|c|c|c|c|c|c|c|c|c|c|}
\hline \multirow{2}{*}{$\begin{array}{l}\text { Days } \\
0\end{array}$} & \multicolumn{15}{|c|}{ Acceptability } \\
\hline & + & + & + & + & + & + & + & + & + & + & & & & & \\
\hline 5 & + & + & + & + & + & + & + & + & + & + & + & & & & \\
\hline 10 & + & + & + & + & + & + & + & -52 & -53 & -54 & -55 & -56 & & & \\
\hline 15 & + & + & + & + & + & + & -45 & -46 & -47 & -49 & -50 & -51 & & & \\
\hline \multirow[t]{2}{*}{18} & + & + & + & + & + & + & + & -32 & -33 & -34 & -35 & -36 & -37 & -38 & -39 \\
\hline & -40 & -41 & -42 & -43 & -44 & & & & & & & & & & \\
\hline \multirow[t]{3}{*}{21} & + & + & + & + & + & -1 & -2 & -3 & -4 & -5 & -6 & -7 & -8 & -9 & -10 \\
\hline & -11 & -12 & -13 & -14 & -15 & -16 & -17 & -18 & -19 & -20 & -21 & -22 & -23 & -24 & -25 \\
\hline & -26 & -27 & -28 & -29 & -30 & -31 & & & & & & & & & \\
\hline
\end{tabular}

Hazard values ( $\mathrm{H}$ values) and cumulative hazard values $(\Sigma \mathrm{H})$ are calculated as a result of the sensory evaluation and shown in Table 6.

In Weibull hazard analysis up to $50 \%$ of the critical error probability is the basis for calculations. In other words, the shelf life is defined as the time corresponding to the cumulative hazard value of $69.3 \%$, was found to be 18.6 days in this study (Fu and Labuza, 1997).

Table 6. Weibull hazard ranking table for cold coffee at $125^{\circ} \mathrm{C}$ and $10 \mathrm{~min}$ without sodium bicarbonate and with carrageenan

\begin{tabular}{|c|c|c|c|c|c|c|c|}
\hline Rank & Days & H Value & $\sum \mathrm{H}$ & Rank & Days & H Value & $\sum \mathrm{H}$ \\
\hline 56 & 10 & 1.79 & 1.79 & 28 & 21 & 3.57 & 72.00 \\
\hline 55 & 10 & 1.82 & 3.60 & 27 & 21 & 3.70 & 75.70 \\
\hline 54 & 10 & 1.85 & 5.46 & 26 & 21 & 3.85 & 79.55 \\
\hline 53 & 10 & 1.89 & 7.34 & 25 & 21 & 4.00 & 83.55 \\
\hline 52 & 10 & 1.92 & 9.27 & 24 & 21 & 4.17 & 87.72 \\
\hline 51 & 15 & 1.96 & 11.23 & 23 & 21 & 4.35 & 92.07 \\
\hline 50 & 15 & 2.00 & 13.23 & 22 & 21 & 4.55 & 96.61 \\
\hline 49 & 15 & 2.04 & 15.27 & 21 & 21 & 4.76 & 101.37 \\
\hline 48 & 15 & 2.08 & 17.35 & 20 & 21 & 5.00 & 106.37 \\
\hline 47 & 15 & 2.13 & 19.48 & 19 & 21 & 5.26 & 111.64 \\
\hline 46 & 15 & 2.17 & 21.65 & 18 & 21 & 5.56 & 117.19 \\
\hline 45 & 15 & 2.22 & 23.87 & 17 & 21 & 5.88 & 123.07 \\
\hline 44 & 18 & 2.27 & 26.15 & 16 & 21 & 6.25 & 129.32 \\
\hline 43 & 18 & 2.33 & 28.47 & 15 & 21 & 6.67 & 135.99 \\
\hline 42 & 18 & 2.38 & 30.85 & 14 & 21 & 7.14 & 143.13 \\
\hline 41 & 18 & 2.44 & 33.29 & 13 & 21 & 7.69 & 150.83 \\
\hline 40 & 18 & 2.50 & 35.79 & 12 & 21 & 8.33 & 159.16 \\
\hline 39 & 18 & 2.56 & 38.36 & 11 & 21 & 9.09 & 168.25 \\
\hline 38 & 18 & 2.63 & 40.99 & 10 & 21 & 10.00 & 178.25 \\
\hline 37 & 18 & 2.70 & 43.69 & 9 & 21 & 11.11 & 189.36 \\
\hline 36 & 18 & 2.78 & 46.47 & 8 & 21 & 12.50 & 201.86 \\
\hline 35 & 18 & 2.86 & 49.33 & 7 & 21 & 14.29 & 216.15 \\
\hline 34 & 18 & 2.94 & 52.27 & 6 & 21 & 16.67 & 232.81 \\
\hline 33 & 18 & 3.03 & 55.30 & 5 & 21 & 20.00 & 252.81 \\
\hline 32 & 18 & 3.13 & 58.42 & 4 & 21 & 25.00 & 277.81 \\
\hline 31 & 21 & 3.23 & 61.65 & 3 & 21 & 33.33 & 311.15 \\
\hline 30 & 21 & 3.33 & 64.98 & 2 & 21 & 50.00 & 361.15 \\
\hline 29 & 21 & 3.45 & 68.43 & 1 & 21 & 100.00 & 461.15 \\
\hline
\end{tabular}

As a result of trials 1,2 and 3 it was determined that the samples in the trial 2 had the longest shelf life. The reason may be interpretation as to that the carrageenan gum used in UHT processes changes the viscosity and undesirable conditions such as precipitation or aggregation have occurred. For example, on the 12th day of trial 1 , fat globules were detected on the surface of the product and aggregation occurred in the product. In Trial 3, on the 15th 
day, it was determined that coffee particles precipitated in the product and the viscosity started to gel. Thus, with these trials, the effect of carrageenan gum on shelf life was determined by using different temperatures during the sterilization phase.

Wittenger and Smith (1986) studied the effect of different stabilizers (guar gum, locust bean gum, carrageenan) on the shelf life of ice cream was tried to be determined using the Weibull hazard analysis method. They found that the shelf life of ice cream which was determined as 4.7 weeks (32.9 days). The shelf life of the cold coffee samples containing carrageenan used in our current study was determined as 28.6 days, which was very close to that found in study of Wittenger and Smith (1986).

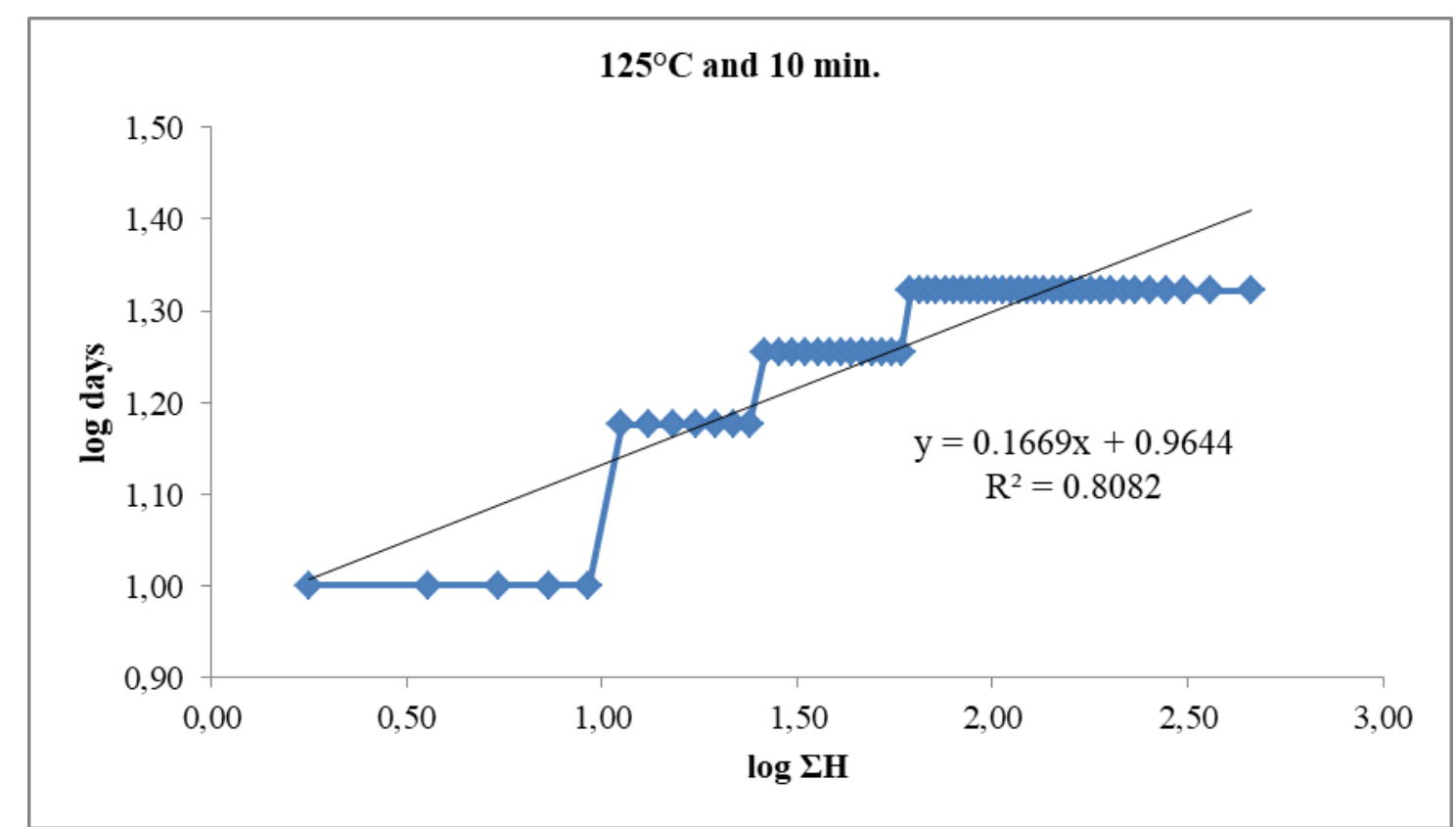

Figure 4: Weibull hazard plot for coffee at $125^{\circ} \mathrm{C}$ and $10 \mathrm{~min}$ without sodium bicarbonate and with carrageenan.

Karahan and Keklik (2018) determined the shelf life of a cold coffee drink containing coconut extract using the Weibull hazard analysis method. They found that the shelf life of cold coffee containing coconut extract was 10.47 days. This shelf life is shorter than the shelf life found in our current research. The possible explanation of this difference may be the amount of carrageenan used in the formulations. While Karahan and Keklik (2018) used $0.025 \%$ carrageenan in their formulation, the coffee prepared in our current study was prepared with a higher gum content (i.e., $0.1 \%(w / w)$.
Determination the shelf life of cold coffee at $120^{\circ} \mathrm{C}$ and 10 minutes with sodium bicarbonate acidity regulator and carrageenan gum

Acidic regulators such as citric acid, trisodium citrate, ascorbic acid and sodium bicarbonate are used to increase the shelf life of many products on the market. Shelf-life analysis of coffee prepared with sodium bicarbonate and carrageenan gum and sterilized at $120^{\circ} \mathrm{C}$ for 10 minutes is given in Table 7. The results of the Weibull analyses with hazard values $(H)$ and cumulative hazard values $(\Sigma \mathrm{H})$ are given in Tables $7 \& 8$. The evaluation of results is presented in Figure 5. 
Table 7. Weibull sensory data for cold coffee at $120^{\circ} \mathrm{C}$ and $10 \mathrm{~min}$ with sodium bicarbonate and Carrageenan

\begin{tabular}{|c|c|c|c|c|c|c|c|c|c|c|c|c|c|c|c|}
\hline Months & Acce & abilit & & & & & & & & & & & & & \\
\hline 0 & + & + & + & + & + & + & + & + & & & & & & & \\
\hline 4 & + & + & + & + & + & + & + & + & + & & & & & & \\
\hline 8 & + & + & + & + & + & + & + & + & + & + & & & & & \\
\hline 12 & + & + & + & + & + & -51 & -52 & -53 & -54 & -55 & -56 & & & & \\
\hline \multirow[t]{2}{*}{14} & + & + & + & + & + & + & + & + & -41 & -42 & -43 & -44 & -45 & -46 & -47 \\
\hline & -48 & -49 & -50 & & & & & & & & & & & & \\
\hline \multirow[t]{2}{*}{16} & + & + & + & + & + & + & + & + & + & + & + & + & + & + & -26 \\
\hline & -27 & -28 & -29 & -30 & -31 & -32 & -33 & -34 & -35 & -36 & -37 & -38 & -39 & -40 & \\
\hline \multirow[t]{3}{*}{18} & + & + & + & + & + & + & + & + & + & + & + & + & + & + & + \\
\hline & + & + & + & -1 & -2 & -3 & -4 & -5 & -6 & -7 & -8 & -9 & -10 & -11 & -12 \\
\hline & -13 & -14 & -15 & -16 & -17 & -18 & -19 & -20 & -21 & -22 & -23 & -24 & -25 & & \\
\hline
\end{tabular}

Table 8. Weibull hazard ranking table for cold coffee at $120^{\circ} \mathrm{C}$ and $10 \mathrm{~min}$ with sodium bicarbonate and Carrageenan

\begin{tabular}{|c|c|c|c|c|c|c|c|}
\hline Rank & Month & H Value & $\sum \mathrm{H}$ & Rank & Month & H Value & $\sum \mathrm{H}$ \\
\hline 56 & 12 & 1.8 & 1.8 & 28 & 16 & 3.6 & 72.0 \\
\hline 55 & 12 & 1.8 & 3.6 & 27 & 16 & 3.7 & 75.7 \\
\hline 54 & 12 & 1.9 & 5.5 & 26 & 16 & 3.8 & 79.6 \\
\hline 53 & 12 & 1.9 & 7.3 & 25 & 18 & 4.0 & 83.6 \\
\hline 52 & 12 & 1.9 & 9.3 & 24 & 18 & 4.2 & 87.7 \\
\hline 51 & 12 & 2.0 & 11.2 & 23 & 18 & 4.3 & 92.1 \\
\hline 50 & 14 & 2.0 & 13.2 & 22 & 18 & 4.5 & 96.6 \\
\hline 49 & 14 & 2.0 & 15.3 & 21 & 18 & 4.8 & 101.4 \\
\hline 48 & 14 & 2.1 & 17.4 & 20 & 18 & 5.0 & 106.4 \\
\hline 47 & 14 & 2.1 & 19.5 & 19 & 18 & 5.3 & 111.6 \\
\hline 46 & 14 & 2.2 & 21.7 & 18 & 18 & 5.6 & 117.2 \\
\hline 45 & 14 & 2.2 & 23.9 & 17 & 18 & 5.9 & 123.1 \\
\hline 44 & 14 & 2.3 & 26.1 & 16 & 18 & 6.3 & 129.3 \\
\hline 43 & 14 & 2.3 & 28.5 & 15 & 18 & 6.7 & 136.0 \\
\hline 42 & 14 & 2.4 & 30.9 & 14 & 18 & 7.1 & 143.1 \\
\hline 41 & 14 & 2.4 & 33.3 & 13 & 18 & 7.7 & 150.8 \\
\hline 40 & 16 & 2.5 & 35.8 & 12 & 18 & 8.3 & 159.2 \\
\hline 39 & 16 & 2.6 & 38.4 & 11 & 18 & 9.1 & 168.3 \\
\hline 38 & 16 & 2.6 & 41.0 & 10 & 18 & 10.0 & 178.3 \\
\hline 37 & 16 & 2.7 & 43.7 & 9 & 18 & 11.1 & 189.4 \\
\hline 36 & 16 & 2.8 & 46.5 & 8 & 18 & 12.5 & 201.9 \\
\hline 35 & 16 & 2.9 & 49.3 & 7 & 18 & 14.3 & 216.1 \\
\hline 34 & 16 & 2.9 & 52.3 & 6 & 18 & 16.7 & 232.8 \\
\hline 33 & 16 & 3.0 & 55.3 & 5 & 18 & 20.0 & 252.8 \\
\hline 32 & 16 & 3.1 & 58.4 & 4 & 18 & 25.0 & 277.8 \\
\hline 31 & 16 & 3.2 & 61.6 & 3 & 18 & 33.3 & 311.1 \\
\hline 30 & 16 & 3.3 & 65.0 & 2 & 18 & 50.0 & 361.1 \\
\hline 29 & 16 & 3.4 & 68.4 & 1 & 18 & 100.0 & 461.1 \\
\hline
\end{tabular}

$120^{\circ} \mathrm{C}$ and $10 \mathrm{~min}$ at sodium bicarbonate

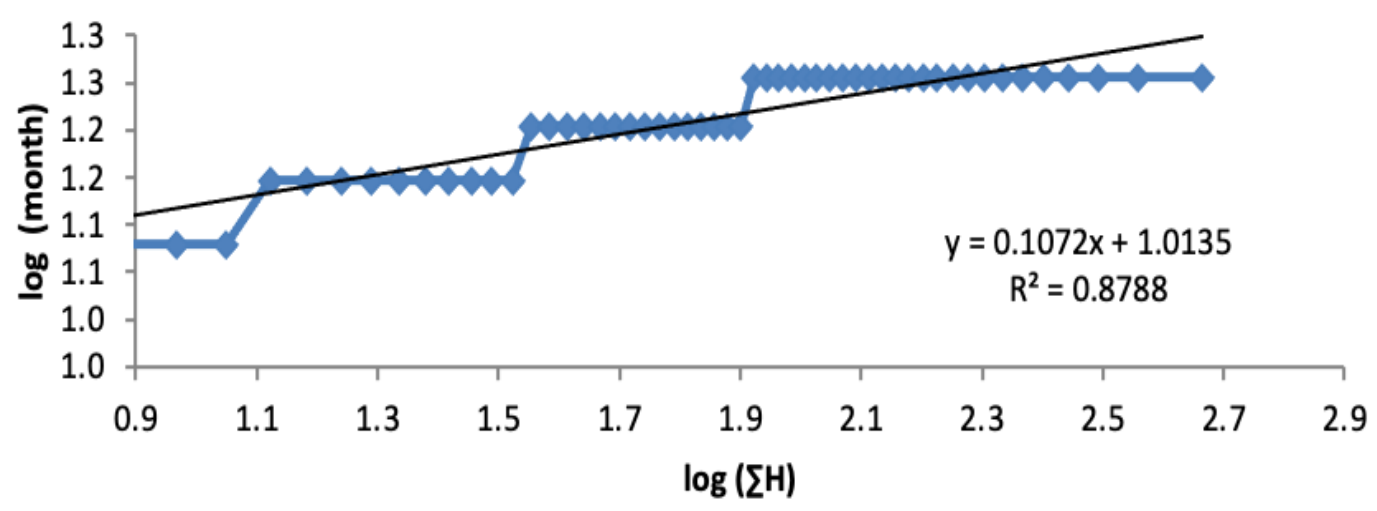

Figure 3 . Weibull hazard plot for coffee at $120^{\circ} \mathrm{C}$ and $10 \mathrm{~min}$ with sodium bicarbonate and carrageenan. 
The shelf life of cold coffee with sodium bicarbonate and carrageenan was calculated as 16.3 months. It is known that many cold coffees and varieties available in the market have a shelf life of 6 to 18 months (Karahan and Keklik, 2018). The reason why the products have a long shelf life may be that they contain acidic regulators (sodium bicarbonate, trisodium citrate, citric acid). The shelf life of the samples produced in our current study was found similar to reported values in the literature (Karahan and Keklik, 2018). An actual picture of the coffee which was stored at room temperature for 15 months is given in Figure 6, showing no obvious sign of deterioration.

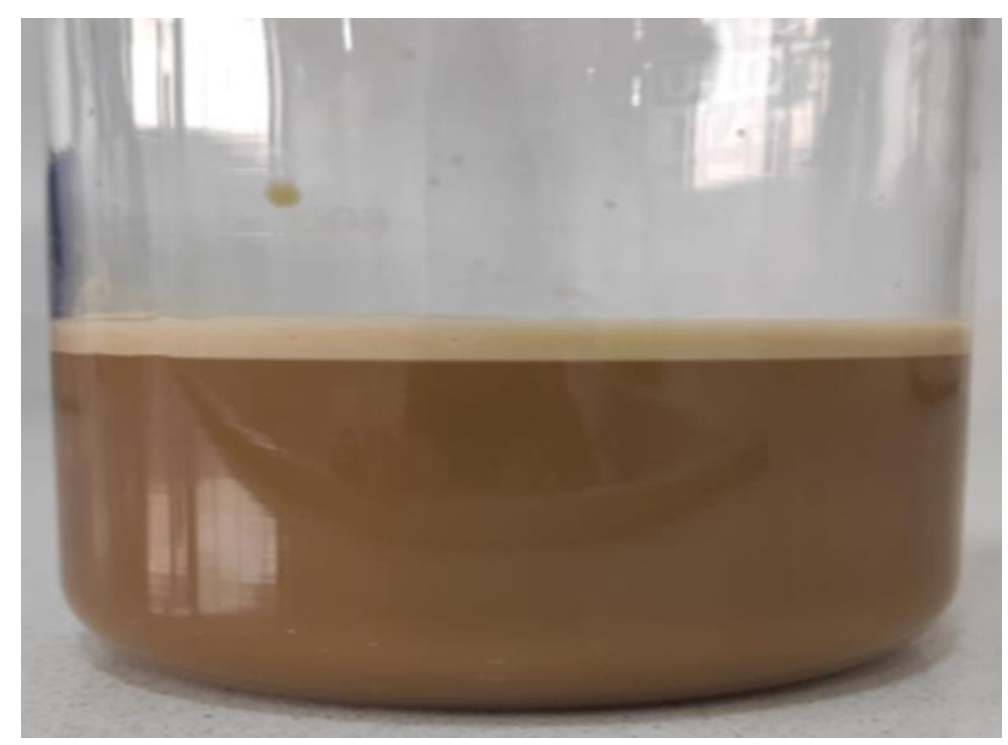

Figure 4. Actual picture of coffee stored for 15 months at room temperature without any obvious deterioration.

\section{Conclusions}

It can be concluded from the results of this research that it is possible to formulate a cold coffee drink which is stable at room temperature for 15 months without any sign of deterioration. It can also be concluded that pistachio nut flavor can be incorporated into the formulation with acceptance from potential customers as shown by high acceptability rates in the taste panels. It is believed that the results obtained in our current study will lead to a clearer understanding of the formulation, shelf life and consumer acceptability of cold coffee drinks with different natural flavors.

\section{Acknowledgements}

Great assistance from Ms. Zeynep Tugba ÖZASLAN (Gaziantep University, Food Engineering Department, Turkey) during the preparation of the manuscript is appreciated. This study has been prepared using data from a part of Ahmet Oğuzhan POLAT's Master Thesis. We would like to thank Gaziantep University, Food Engineering Department and Meridyen Gıda R\&D (Gaziantep, Turkey) engineers for supporting the study.

Conflict of interest: The authors declare that they have no conflict of interest.

Author contributions: Ahmet Oğuzhan Polat and Şenol Ibanoğlu designed the research outline. Ahmet Oğuzhan Polat carried out the experimental work. Both authors evaluated the data and wrote the article. Both authors read and approved the final manuscript.

\section{References}

Akbulut, Ç, \& Bozkurt, A. (2020). Impact of pH on the salty taste perception of the yogurt drink, ayran. Harran Tarım ve Gıda Bilimleri Dergisi, 24(3), 301-309.

Andujar, G., \& Herrera, H. (1987). The distribution of failure 
data for meat products. The 33th European Meeting of Meat Research Workers, (pp. 396-398), 2-7 August 1987, Helsinki, Finland.

Araújo, J. M., \& Sandi, D. (2007). Extraction of coffee diterpenes and coffee oil using supercritical carbon dioxide. Food Chemistry, 101(3), 1087-1094.

DOI: https://doi.org/10.1016/j.foodchem.2006.03.008

Cardelli, C., \& Labuza, T. P. (2000). Application of Weibull hazard analysis to the determination of the shelf life of roasted and ground coffee. LWT-Food Science and Technology, 34(5), 273-278. DOI: 10.1006/fstl.2000.0732

Carpenter, R. P., Lyon, D. H., \& Hasdell, T. A. (2000). Guidelines for Sensory Analysis in Food Product Development and Quality Control. New York: Springer Science \& Business Media. DOI: 10.1007/978-1-4615-4447-0

Duyvesteyn, W. S. (1997). Integration of the timetemperature history effect on the shelf life of fluid milk. PhD Thesis. University of Minnesota, Minnesota, USA.

Fu, B., \& Labuza, T. P. (1993). Shelf-life prediction: theory and application. Food Control, 4(3), 125-133.

Fu, B., \& Labuza, T. P. (1997). Shelf-life testing: procedures and prediction methods. In: Erickson M. C. (ed.), Quality in Frozen Foods (pp 377-415). New York: Chapman \& Hall. DOI: 10.1007/978-1-4615-59757_19

Gacula J., M. C., \& Kubala, J. J. (1975). Statistical models for shelf-life failures. Journal of Food Science, 40(2), 404409.

Hayoğlu, ì., \& Toğrul, Ö. (2020). Yeni bir izotonik içecek olarak; nar, kızılcık ve karadut suları ile zenginleştirilmiş elma suyu üretim olanakları. Harran Tarım ve Gıda Bilimleri Dergisi, 24(2), 165-173.

ICO, (2017). Domestic consumption by all exporting countries. Retrieved from: http://www.ico.org/Market-Report-17-18-e.asp.

Karahan, D., \& Keklik, N. M. (2018). Hindistan cevizi ekstraktı içeren soğuk kahve içeceğinin geliştirilmesi ve raf ömrünün belirlenmesi. Gıda,43(6), 906-916. DOI: $10.15237 /$ gida.GD18054
Keklik, N. M., Işıklı, N. D., \& Sur, E. B. (2017). Estimation of the shelf life of pezik pickles using Weibull hazard analysis. Food Science and Technology, 37, 125-130. DOI: 10.1590/1678-457x.33216

Kilcast, D., \& Subramaniam, P. (2000). Stability and Shelf-life of Food. New York: Woodhead Publishing Limited and CRC Press LLC.

Labuza, T. P., \& Schmidl, M. K. (1988). Use of sensory data in the shelf-life testing of foods: principles and graphical methods for evaluation. Cereal Foods World, 33, 193-206.

Pickering, S. C. (1984). Prediction and analysis of shelf life of an oat bran cereal.MSc Thesis. University of Minnesota, Minnesota, USA.

Schmidt, K., \& Bouma, J. (1992). Estimating shelf-life of cottage cheese using hazard analysis. Journal of Dairy Science, 75(11), 2922-2927.

Shakerardekani, A., Karim, R., \& Vaseli, N. (2012). The effect of processing variables on the quality and acceptability of pistachio milk. Journal of Food Processing and Preservation, 37(5), 541-545. DOI: 10.1111/j.1745-4549.2012.00676.x

Shirose, I., Aguirre, J. M., \& Ferreira, V. L. P. (1978). Application of a staggered experimental design to study of the shelf-life of cassava flour enriched with soybean protein extraction residue. Coletânea do Instituto de Tecnologia de Alimentos, 9, 313-334.

Thiemig, F., Buhr, H., \& Wolf, G. (1998). Characterization of shelf-life and spoilage of fresh foods-First results with the Weibull hazard analysis. Fleischwirtschaft, 78(2), 152-154.

Tomasicchio, M., Andreotti, R., Pirazzoli, P., \& Pezzani, G. (1989). Application of the Weibull statistical model to the shelf-life of some frozen foods. Industria Conserve, 64(2), 102-109.

Wittenger, S. A., \& Smith, D. E. (1986). Effect of sweeteners and stabilizers on selected sensory attributes and shelf life of ice cream. Journal of Food Science, 51(6), 1463-1466. DOI: 10.1111/j.13652621.1986.tb13835.x 